DOI 10.17805/zpu.2018.4.28

\title{
Научные понятия как теоретико-методологическая основа современных психологических исследований
}

\author{
Ю. Н. ОЛЕЙНИК, В. М. ЗВОНИКОВ, О. В. ЛУНЕВА \\ МОСКОВСКИЙ ГУМАНИТАРНЫЙ УНИВЕРСИТЕТ
}

Рецензия на издание: Разработка понятий современной психологии / отв. ред. А. Л. Журавлев, Е. А. Сергиенко. М. : Изд-во «Институт психологии РАН», 2018. 702 с.

Ключевые слова: рецензия; психология; понятийный аппарат; теория психологии; понятие

$\mathrm{P}$ астущий практический запрос к психологии, актуализация внимания к теоретическим и методологическим основам проводимых психологических исследований, необходимость научной рефлексии пройденного пути и достижений, размышления о перспективных линиях дальнейшего развития психологического знания с закономерной необходимостью ставят вопрос о систематизации и более четкой категоризации понятийного поля современной российской психологии. Это задача не только важная, но и ответственная, не говоря уже о ее дискуссионности. Понимая все это, авторский коллектив Института психологии РАН решился на подготовку фундаментального труда по данной проблеме. Речь о коллективной монографии «Разработка понятий современной психологии», которая вышла в свет в 2018 г. в серии «Методология, теория, история психологии» под редакцией А. $\Lambda$. Журавлева и Е. А. Сергиенко (Разработка понятий ..., 2018).

Во вступительной статье, представляющей несомненную и самостоятельную научную, а для кого-то, возможно, еще и познавательную ценность, прослеживается история и современное состояние разработки системы понятий в отечественной психологии. Ее авторы, ответственные редакторы монографии, обращаются в первую очередь к анализу взглядов и концептуальных подходов тех ученых, кто, начиная со второй трети XX столетия, активно и продуктивно работал в пространстве структурирования и систематизации категориально-понятийного аппарата психологической науки: работам М. Г. Ярошевского, А. В. Петровского, К. К. Платонова, Я. А. Пономарева, $\Lambda$. И. Анцыферовой и др. При этом важно подчеркнуть, что работа, начатая корифеями советской психологии, получает продолжение и конструктивное развитие, как показывают авторы статьи, в целом ряде публикаций уже современных российских психологов. Тем самым акцентируется внимание на преемственности и одновременно на незавершенности работы по созданию понятийной системы современной психологии. Впрочем, авторы статьи специально подчеркивают, что в задачи монографии и не входило создание такой системы, что речь в ней идет лишь о понятиях, разрабатываемых в рамках научной школы Института психологии РАН (там же: 42).

В монографии в трех разделах рассматриваются соответственно три группы понятий: понятия в общей теории психологии (индивидуальный субъект, коллективный субъект, менталитет, психологические отношения, интеллект, инсайт), понятия в современных отраслях психологии (модель психического, контроль поведения, социальное представление, коллективный образ будущего, дискурс, интенция, дискурсивные способности, специальные способности, стиль деятельности), понятия в рамках прикладных направлений психологических исследований (жизнеспособность человека, субъективный возраст, компенсация, психологическое здоровье, счастье, патрио- 
тизм). Авторы статей (каждому понятию соответствует самостоятельная статья) авторитетные и признанные специалисты в области академической и прикладной психологии - как правило, рассматривают историю формирования понятия, раскрывают его содержание, соотносят с совокупностью существующих близких понятий. Это делает монографию не только значимой для решения теоретико-методологических вопросов современной психологии, но и позволяет рассматривать ее как серьезный вклад в историю психологии, в частности в историю формирования и развития понятийного поля отечественной психологии.

Важным выводом, который делают ответственные редакторы, анализируя содержание коллективного труда, является фиксация ключевых характеристик современных трактовок понятий. В число таких характеристик они включают: интегративный и междисциплинарный характер психологических понятий; расширение содержания понятий и использование их в широком тематическом поле; изменение организационной структуры понятий и превращение отдельных понятий в интегрированные понятийные образования, в которых «имплицитно представлены многие базовые психологические конструкты, которые трудно уже эксплицировать как единичные» (там же: 53); субъектность понятий, трактуемую как субъектность разработчика понятия и творца понятийного анализа и субъектность как соотнесенность всех понятий, анализируемых в книге, с категорией субъекта.

Указанные характеристики, по мнению А. $А$. Журавлева и Е. А. Сергиенко, в полной мере «отражают новый этап развития методологии науки, этап метамодернизма» (там же: 55). Таким образом, можно констатировать, что рецензируемая коллективная монография является одним из первых научных изданий в области методологии психологии, которая в пространстве понятийного поля психологии пытается осмыслить феномен метамодернизма как глобального культурного процесса, характеризующегося колебаниями между противоположностями и стремлением использовать эти противоположности одновременно в мировосприятии, точнее в мироощущении человеком своего бытия.

Значимой и вызывающей симпатию характеристикой коллективной монографии является ориентация ее авторов не столько на окончательное решение теоретических и методологических вопросов в области категориально-понятийного аппарата современной психологии, а стремление на основе предлагаемого материала пригласить коллег к диалогу относительно понятийного поля отечественной психологической науки.

Одним из направлений такого коллективного диалога может явиться обсуждение дефиниций обосновываемых и разрабатываемых авторами понятий с соблюдением общепринятых правил подобных логических процедур (соразмерность определений; невозможность определения понятия через самое себя; определение не должно быть отрицательным, так же как и двусмысленным; невозможность определения через термины, которые сами нуждаются в определении, и др.).

В целом можно отметить, что современная теория и методология психологии обогатились с изданием данной коллективной монографии более чем обстоятельным и крайне необходимым научным трудом. Он не только привлекает внимание к одной из важных проблем любой науки - работе над осмыслением и новой трактовкой уже используемых научных понятий в контексте актуальных изменений в пространстве гуманитарного знания, не только побуждает исследователей более уверенно вести работу по фиксации в виде понятий новых реалий и феноменов своей предметной обла- 
сти, но и обращает внимание исследователей на необходимость преодоления, перефразируя Я. А. Пономарева, «понятийной многоаспектности», чего не лишена современная отечественная психология.

\section{СПИСОК АИТЕРАТУРЫ}

Разработка понятий современной психологии (2018) / отв. ред. А. А. Журавлев, Е. А. Сергиенко. М. : ИзА-во «Институт психологии РАН». 702 с.

Аата поступления: 10.11.2018 2.

\section{SCIENTIFIC CONCEPTS AS THEORETICAL AND METHODOLOGICAL BASIS \\ OF THE CONTEMPORARY PSYCHOLOGICAL RESEARCH \\ YU. N. OLEYNIK, V. M. ZVONIKOV, O. V. LUNEVA \\ MOSCOW UNIVERSITY FOR THE HUMANITIES}

A review of the publication: Razrabotka poniatii sovremennoi psikhologii (2018) / ed. by A. L. Zhuravlev and E. A. Sergienko. Moscow, RAS Institute of Psychology Publishing, 2018. 702 p.

Keywords: review; psychology; conceptual apparatus; metapsychology; concept

\section{REFERENCES}

Razrabotka poniatii sovremennoi psikbologii (2018)/ ed. by A. L. Zhuravlev and E. A. Sergienko. Moscow, Izd-vo «Institut psikhologii RAN». 702 p. (In Russ.).

Submission date: 10.11.2018.

Олейник Юрий Николаевич - кандидат психологических наук, доцент, заведующий кафедрой общей психологии и истории психологии Московского гуманитарного университета. ААpec: 111395, Россия, г. Москва, ул. Юности, А. 5. Тел.: +7 (499) 374-67-20. Эл. адрес: уuoleјnik@mosgu.ru

Звоников Вячеслав Михайлович - доктор медицинских наук, профессор, заместитель завеАующего кафедрой общей психологии и истории психологии Московского гуманитарного университета. Адрес: 111395, Россия, г. Москва, ул. Юности, А. 5. Тел.: +7 (499) 374-67-20. Эл. аАpec: k_opsy@mail.ru

Иунева Ольга Викторовна - кандидат психологических наук, доцент, профессор кафедры социальной и этнической психологии Московского гуманитарного университета. ААрес: 111395, Россия, г. Москва, ул. Юности, д. 5. Тел.: +7 (499) 374-56-11. Эл. адрес: ksep@mosgu.ru

Oleynik Yuriy Nikolayevich, Candidate of Psychology, Associate Professor, Head, Department of General Psychology and History of Psychology, Moscow University for the Humanities. Postal address: 5, Yunosti St., Moscow, Russian Federation, 111395. Tel.: +7 (499) 374-67-20. E-mail: yuolejnik@mosgu.ru

Zvonikov Vyacheslav Mikhailovich, Doctor of Medicine, Professor, Deputy Head, Department of General Psychology and History of Psychology, Moscow University for the Humanities. Postal address: 5, Yunosti St., Moscow, Russian Federation, 111395. Tel.: +7 (499) 374-67-20. E-mail: k_opsy@mail.ru

Luneva Olga Viktorovna, Candidate of Psychology, Associate Professor, Professor, Department of Social and Ethnic Psychology, Moscow University for the Humanities. Postal address: 5, Yunosti St., Moscow, Russian Federation, 111395. Tel.: +7 (499) 37456-11. E-mail: ksep@mosgu.ru 